\title{
O oráculo de Khliébnikov
}

\author{
Mário Ramos Francisco Jr.
}

De que opressão, de que liberdade estaria falando Vielímir Khliébnikov em seu curto poema, ao indagar com tanta insistência à noite/oráculo sobre o destino que o aguarda?

Khliébnikov foi um poeta engajado no movimento Cubo-futurista russo, que por sua vez estava engajado no movimento político e social que levaria à Revolução Socialista de 1917. Nunca saberemos se este poema, escrito em 1912 (portanto, cinco anos antes do acontecimento), trata das aspirações de um jovem revolucionário. Tampouco se foi motivado por alguma questão mais íntima.

À época em que o poema foi criado, Khliébnikov talvez ainda não trabalhasse com as experiências que culminariam na radicalidade da ininteligível linguagem zaúm. Aqui, a escolha lexical é bem simples. Não há neologismos, e a estrutura das rimas segue um esquema bastante comum (AA/BB/CC). Talvez esta simplicidade imponha-se como a maior dificuldade numa tradução poética para outra língua.

Para manter, em português, a estrutura das rimas fiel à do texto original, foram necessárias algumas intervenções criativas, como por exemplo em "livro de brilhantes letras", ou "opressão para os meus dias". Por outro lado, foi recuperada a simplicidade e o eco da rima entre $\circ 3^{\circ}$ e o $4^{\circ}$ versos, na transliteração: "cníga/íga", com a solução "irradias/dias". Uma das versões que se apresentou anteriormente para este $4^{\circ}$ verso foi "devo ler a opressão em tuas linhas frias?". Além de muito longo, prejudicando a fluência na leitura do poema, o verso dessa maneira traria uma nova intervenção poética "linhas frias" que, acres- 
cida de "livro de brilhantes letras", tornaria redundante a metáfora noite/livro.

Outro resultado interessante obtido foi o que permitiu a rima entre os dois últimos versos. Na tradução literal, teríamos como último verso "no amplo céu da meia-noite". A idéia de amplidão em "céu sem idade" possibilitou a manutenção da rima com o verso anterior "liberdade".

O poema tem metrificação irregular no original. A metrificação da versão em português mantém-se irregular, porém com versos um pouco mais longos, já que a língua russa é bem mais sintética.

Talvez a licença poética mais importante desta tradução esteja no uso do verbo no imperativo "revela", no $2^{\circ}$ verso. Esta palavra, inexistente no original, carrega a subjetividade da metáfora mais importante do poema de V. Khliébnikov: a noite vista como um oráculo. 
Ночь, полная созвездий.

Какой судьбы, каких известий

Ты широко сияешь, книга?

Свободы или ига?

Какой прочесть мне должно жребий

На полночью широком небе?

В. Хлебников (1912)

Notch, pólnaia sosviésdi.

Cacói súdbi, caquíkh isviésti

Ti chiróka siáiech, cníga?

Svabódi ili íga?

Cacói protchiést minié dóljino jiriébi

Na palnótchiu chirócom niébi?

Noite repleta de estrelas.

Revela, livro de brilhantes letras,

Que destino, que notícias irradias?

Opressáo para os meus dias?

Ou palavras de liberdade

À meia-noite de um céu sem idade?

Trad. de Mário Ramos Francisco Jr. 